\title{
Correlation of HER2/neu antibody response to clinical response in a Phase II trial of the ae37+gm-csf her2 peptide vaccine
}

\author{
Julia Greene ${ }^{1 *}$, Erika Schneble ${ }^{1}$, Jonathan Martin", Maddie Flores ${ }^{1}$, Alfred Trappey ${ }^{1}$, John Berry ${ }^{1}$, Timothy Vreeland ${ }^{1}$, \\ Diane Hale ${ }^{1}$, Guy Clifton², Sonia A Perez ${ }^{3}$, Michael Papamichail ${ }^{3}$, George Peoples ${ }^{4}$, Elizabeth Mittendorf², \\ Sathibalan Ponniah ${ }^{5}$
}

From Society for Immunotherapy of Cancer 29th Annual Meeting

National Harbor, MD, USA. 6-9 November 2014

\section{Background}

We are conducting a Phase II clinical trial of the HER2 peptide vaccine AE37+GM-CSF for prevention of breast cancer recurrence in disease-free, node-positive or highrisk node-negative patients, who have completed standard of care therapy. AE37, an Ii-Key hybrid of the HER2/neu derived peptide AE36 (aa:776-790), is an MHC Class II epitope capable of stimulating CD $4^{+}$ helper $\mathrm{T}$ cells. Here, we examine the relationship between HER2 antibody response (AR) and clinical recurrence (CR).

\section{Methods}

Patients with any level of HER2 expression (IHC1-3+) were randomized to receive six monthly intradermal inoculations of AE37+GM-CSF or GM-CSF alone (controls) during the primary vaccination series (PVS) then four booster vaccinations administered every six months. Prior to vaccination (R0) and after the PVS (R6), serum samples were tested for AR against 178 overlapping 17mer peptides spanning the entire HER2 protein molecule. Using flow cytometry, the percentage of anti-HER2 specific antibodies was measured and expressed as mean fluorescent intensity (MFI). Sub group analysis was completed on HER2 over-expressers (OE) (IHC3+) versus non over-expressers (nOE) (IHC1-2+) and hormone receptor positive $(\mathrm{HR}+$ ) (ER or $\mathrm{PR}+$ ) versus $\mathrm{HR}$ patients. Data are means and compared using a chisquare and students $t$ test as appropriate.

${ }^{1}$ San Antonio Military Medical Center, Fort Sam Houston, TX, USA Full list of author information is available at the end of the article

\section{Results}

Of 298 enrolled patients, 153 were vaccinated while 145 were randomized to the control arm. Ten nonrecurrent (NR) and five recurrent (R) vaccinated patients were selected and matched for clinico-pathologic factors. HER2 AR was less in NR versus $R$ at R0 $(3659 \mathrm{mfi} \pm 70$ vs $4799 \mathrm{mfi} \pm 170, \mathrm{p}<0.01)$ and $\mathrm{R} 6(3832 \mathrm{mfi} \pm 82$ vs $4832 \mathrm{mfi} \pm 30, \mathrm{p}<0.01) . \Delta \mathrm{R} 6(\mathrm{R} 6-\mathrm{R} 0)$, AR change postPVS, was increased in NR compared to $R$ patients $(174 \mathrm{mfi} \pm 36$ vs $33 \mathrm{mfi} \pm 70, \mathrm{p}<0.07)$. AR was greater in HER2 OE compared to nOE (R0: $4991 \mathrm{mfi} \pm 169$ vs $3563 \mathrm{mfi} \pm 70$, R6: $4721 \mathrm{mfi} \pm 127$ vs $3888 \mathrm{mfi} \pm 84$, $\mathrm{p}<$ 0.01). nOE exhibited larger $\triangle$ R6 HER2 AR $(325 \mathrm{mfi} \pm 36$ vs $-269.96 \mathrm{mfi} \pm 69, \mathrm{p}<0.01)$. AR was greater in $\mathrm{HR}+$ compared to HR- at R0 $(4214 \mathrm{mfi} \pm 91$ vs $3336 \mathrm{mfi} \pm 62$, $\mathrm{p}<0.01)$ and R6 (4448mfi \pm 86 vs $3037 \mathrm{mfi} \pm 54, \mathrm{p}<$ $0.01)$ with $H R+$ patients exhibiting larger $\triangle R 6$ HER2 AR $(233 \mathrm{mfi} \pm 40$ vs $-299 \mathrm{mfi} \pm 36, \mathrm{p}<0.01)$.

\section{Conclusions}

In a prospective Phase II trial of a CD4+-eliciting HER2 peptide vaccine, AE37+GM-CSF, patients who recur have higher levels of pre-existing antibodies and lower levels of antibody induction. This suggests that induction, not amplification, of an immune response may be important. Significantly higher AR change post-vaccination in HER2 nOE and HR+ patients suggests benefit of vaccination in less aggressive disease.

\section{References}

Trial Registry at clinicaltrials.gov: Vaccine Therapy in Treating Patients With Breast Cancer. Unique Identifying Number: NCT00524277. 


\section{Authors' details}

${ }^{1}$ San Antonio Military Medical Center, Fort Sam Houston, TX, USA. ${ }^{2}$ MD Anderson Cancer Center, Houston, TX, USA. ${ }^{3}$ Cancer Immunology Immunotherapy Center, Saint Savas Cancer Hospital, Athens, Greece. ${ }^{4}$ Cancer Vaccine Development Program, Uniformed Services University of the Health Sciences, Bethesda, MD, USA. ${ }^{5}$ Uniformed Services University of the Health Sciences, Bethesda, MD, USA.

Published: 6 November 2014

doi:10.1186/2051-1426-2-S3-P90

Cite this article as: Greene et al:: Correlation of HER2/neu antibody

response to clinical response in a Phase II trial of the ae37+gm-csf her2 peptide vaccine. Journal for ImmunoTherapy of Cancer 2014 2(Suppl 3):P90.

Submit your next manuscript to BioMed Central and take full advantage of:

- Convenient online submission

- Thorough peer review

- No space constraints or color figure charges

- Immediate publication on acceptance

- Inclusion in PubMed, CAS, Scopus and Google Scholar

- Research which is freely available for redistribution

Submit your manuscript at www.biomedcentral.com/submit
C Biomed Central 